\title{
Suppression of tumorigenicity and metastatic potential of melanoma cells by transduction of interferon gene
}

\author{
A. A. Lykhova, Yu. I. Kudryavets, N. A. Bezdenezhnykh, \\ N. I. Semesiuk, I. N. Adamenko, A. L. Vorontsova \\ R. E. Kavetsky Institute of Experimental Pathology, Oncology and Radiobiology, NAS of Ukraine \\ 45, Vasylkivska Str., Kyiv, Ukraine, 03022 \\ AlexxDNA@gmail.com
}

\begin{abstract}
The aim of this study was to investigate an inhibitory effect of baculovirus-mediated transduction of the murine interferon-beta gene on mouse melanoma in vitro and in vivo. Methods. Studies were performed on B16 mouse melanoma (MM-4 cell line). Transduction, immunocytochemical and tumor cell biology approaches have been used in this study. Results. Transduction of MM-4 cells by the recombinant baculovirus with IFN-beta gene is accompanied by morphological changes of tumor cells, suppression of cell proliferation, significant inhibition of platting efficiency of cells and their colonies formation in semisolid agar. Moreover, transduction of melanoma MM-4 cells by the baculovirus IFN-transgene leads to inhibition of tumorigenicity and metastatic ability of the cells in vivo. The intravenous administration of recombinant baculovirus vector with IFN gene inhibits growth of metastases induced in the lungs of mice by intravenously injected tumor cells. Conclusions. Transduction of mouse melanoma cells by the recombinant baculovirus with murine IFN-beta gene inhibits their proliferative potential, tumorigenicity and metastatic activity.
\end{abstract}

Keywords: interferon, recombinant baculovirus, transduction, melanoma cells, tumorigenicity, metastasis.

Introduction. Interferon (IFN) as a direct antitumor factor or as a part of complex cancer treatment aimed at reducing the risk of metastatic process and improving the quality of life of cancer patients is sufficiently substantiated by experimental and clinical studies [1]. It is known that IFN binding to surface cell receptors leads to activation of intracellular signaling cascades followed by synthesis of IFN-induced proteins. It provides many anticancer effects which can be grouped into three main sets - antiproliferative, immunomodulating and antiangiogenic. At this time, many of the IFN-activated cellular genes are classified as tumor suppressor genes [2].

Regarding clinical efficacy of IFN it should be noted that its use in monotherapy of the patients with solid tumors, in some cases was not quite efficient. This is due to the fact that the bulk of the tumor and high rate of

(C) Institute of Molecular Biology and Genetics, NAS of Ukraine, 2014 its growth do not leave enough time for manifestation of the entire spectrum of antitumor properties of IFN, and its growth-inhibitory effect can be realized only under conditions of high local concentrations of cytokines in the tumor and/or high sensitivity of tumor cells to the action of IFN [3]. However, the corresponding concentration of IFN protein in tumors is not always possible to create by parenteral administration because of its rapid clearance and high systemic toxicity [4]. Gene therapy for cancer treatment based on the use of genetic structures with IFN gene is a new approach that allows creating a sufficiently high constant concentration of cytokine in the tumor. The transduction of only $1 \%$ of tumor cells with IFN gene was found to lead actually to the inhibition of tumor growth and tumor angiogenesis due to a high local production of IFN [5].

At this time, the gene therapy used different viral vector systems: based on adeno-, lenti- and retroviru- 
ses, herpes virus group and others. All these systems have limitations and drawbacks [6]. Interest to baculoviruses as potential vectors of recombinant molecules is due to their ability to provide genetic transduction elements of significant size in mammalian cells and to control their expression and synthesis of large quantities of recombinant proteins [7].

A significant advantage of the recombinant baculovirus system is the lack of replication of the virus and a low level of synthesis of viral proteins in mammalian cells, as well as low cytopathogenic effect of baculovirus in these cells [8].

Therefore, it was logical to use such vector system to determine IFN production in tumor cells and to study the changes of biological characteristics of the mouse melanoma cells transduced by the recombinant baculovirus without IFN gene (rBV) and recombinant baculovirus with mouse inf- $\beta$ gene (rBV/IFN).

Materials and methods. Recombinant baculovirus vectors were kindly provided by Dr. L. I. Strokovska (Institute of Molecular Biology and Genetics, NAS of Ukraine). Recombinant baculovirus vectors were based on nuclear polyhedrosis virus Autographa californica (Ac) and obtained using baculovirus expression system Bacto-Bac («Invitrogen», USA): $\mathrm{rBV} / \mathrm{IFN}\left(5 \cdot 10^{8} \mathrm{pfu} / \mathrm{ml}\right)$ and as a control $-\mathrm{rBV}\left(2,5 \cdot 10^{8} \mathrm{pfu} / \mathrm{ml}\right)$.

inf $-\beta$ genes were under the control of strong $\mathrm{CAG}$ promoter cassette $[9,10]$.

Cells of mouse melanoma B16 (cell line MM-4) $[11,12]$ and L929 cells were provided by Bank of Cell Line of R. E. Kavetsky Institute of Experimental Pathology, Oncology and Radiobiology, NAS of Ukraine (IEPOR) and maintained in plastic flask («TPP», Italy) in DMEM $4 \mathrm{mmol} / \mathrm{l} \mathrm{L-glutamine} \mathrm{(«Sigma»,} \mathrm{USA)} \mathrm{with}$ $10 \%$ newborn calf serum (NCS) («Sigma») and 40 $\mathrm{mg} / \mathrm{ml}$ gentamicin («Sigma»). The cells were incubated at temperature $37{ }^{\circ} \mathrm{C}$ in a humidified atmosphere with $5 \% \mathrm{CO}_{2}$.

Transduction of cells was performed at multiplicity of infection (MOI) of rBV and rBV/IFN (MOI = number of pfu rBV and rBV/IFN per cell) 100 and 200.

The cells of MM-4 in RPMI-1640 medium were mixed in PBS with the virus in a 1:1 ratio for $2 \mathrm{~h}$ at room temperature and then with adding a complete culture medium the cells were incubated $24-96 \mathrm{~h}$ at $37^{\circ} \mathrm{C}$ and $5 \% \mathrm{CO}_{2}$.
The serum of experimental animals and the culture medium of MM-4 cells transduced with $\mathrm{rBV}$ and $\mathrm{rBV} /$ IFN were stored at $-20{ }^{\circ} \mathrm{C}$. The titer of mouse IFN-beta was determined by standard micromethod on antiviral activity. L929 cells and vesicular stomatitis virus (VSV) were used as a test-system [13].

The IFN titer was expressed in international units (IU). Mouse IFN-beta Cat. N 19032 («Sigma») was used as a standard.

Proliferative potential and synthesis of recombinant murine IFN-beta of melanoma cells transduced with rBV and $\mathrm{rBV} / \mathrm{IFN}$ were determined by immunocytochemical evaluation of the cells expressing Ki-67 protein (marker of DNA replication) and IFN-beta protein. Immediately after transduction, the cells were planted on the coverslip slides and 20-48 h later an analysis was conducted by the standard method [14] using monoclonal antibodies against Ki-67 or against mouse IFN-beta («Thermo Scientific», USA). To visualize the reaction of antigen/antibody the Ultra Vision LPValue Detection system («Thermo Scientific») was used. As a chromogen was used DAB Quanto (3,3-diaminobenzidin) («Thermo Scientific»).

To determine the platting efficiency on the substrate, the MM- 4 cells ( $24 \mathrm{~h}$ after transduction) were plated in paired wells of 6-well plates («ТРP») at a density of 200 cells per well in the complete growth medium (DMEM with $10 \% \mathrm{NCS}$ and $40 \mathrm{mg} / \mathrm{ml}$ gentamicin) and incubated at $37^{\circ} \mathrm{C}$ in $5 \% \mathrm{CO}_{2}$. After 14 days the colonies of the cells were stained with the crystal violet dye («Sigma») [15]. The number of colonies and their size were determined in each well using binocular magnifier BM-51-2 («LOMO», Russian Federation).

The colony-forming ability of MM-4 cells in semisolid agar was estimated in $0.33 \%$ agar («Difco», USA) in DMEM plus $10 \%$ NCS in vitro [16]. The plates were incubated for 14 days in a humid atmosphere at $37{ }^{\circ} \mathrm{C}$ in the presence of $5 \% \mathrm{CO}_{2}$, then the number and the size of colonies were determined in each well using binocular magnifier BM-51-2 («LOMO»). The size of colony was defined as small (10-20 cells), middle ( $21-50$ cells) and large (more than 50 cells) [17].

Morphology of live MM-4 cells culture was analyzed by inverted microscope Axiovert 25 («Carl Zeiss», Germany) equipped with digital camera («Canon Power Shot A640», UK) in 100-320 times magnification. 
IFN-beta production and proliferatve ativity of MM-4 cells transduced with different types of recombinant baculovirus

\begin{tabular}{c|c|c|c|c}
\hline Virus & MOI, pfu/cell & Titer IFN-beta, IU/ml & Living cells, $\%$ & Ki-67-positive cells, \% \\
\hline Control & - & 0 & 100.0 & $96 \pm 1.5$ \\
rBV & 100 & 0 & $73.0 \pm 3.8^{* *}$ & $95.7 \pm 1.2$ \\
rBV/IFN & 100 & 5000 & $36.5 \pm 3.2^{*}$ & $39.2 \pm 8.3^{* * *}$ \\
rBV/IFN & 200 & 10000 & $25.3 \pm 2.4^{* *}$ & Not determined \\
\hline
\end{tabular}

N o t e. ${ }^{*} \mathrm{p}<0.005 ; * * \mathrm{p}<0.01 ; * * * \mathrm{p}<0.001$ compared to control.

Tumorigenic and metastatic properties of MM-4 cell line transduced with $\mathrm{rBV}$ and $\mathrm{rBV} / \mathrm{IFN}$ were determined in the experiments in vivo using C57BL/6 mice aged 7-8 weeks and weight of 20-22 $\mathrm{g}$ in wiring vivarium of R. E. Kavetsky IEPOR NAS of Ukraine. The mice were kept under standard conditions with granulated feed and water ad labidum. The animals were euthanized using either anesthesia. The MM-4 cells transduced with $\mathrm{rBV}$ and $\mathrm{rBV} / \mathrm{IFN}$ at MOI $100 \mathrm{pfu} / \mathrm{cell}$ were used for experiments in vivo.

The suspensions of control and transduced MM-4 cells (at a dose $2 \cdot 10^{5}$ cells per mouse in saline solution) were injected to animals intramuscularly $(\mathrm{i} / \mathrm{m})$ in a volume of $0.1 \mathrm{ml}$ or intravenously (i/v) in a volume of $0.2 \mathrm{ml}$ (experimental metastasis). $\mathrm{rBV}$ and $\mathrm{rBV} / \mathrm{IFN}$ were injected intratumorally $(\mathrm{i} / \mathrm{t})$ three times on the $10^{\text {th }}$, $13^{\text {th }}$ and $15^{\text {th }}$ days of tumor growth at a dose $5 \cdot 10^{7} \mathrm{pfu}$ per mouse in a volume of $0.1 \mathrm{ml}$.

To investigate the experimental metastasis $\mathrm{rBV}$ and $\mathrm{rBV} / \mathrm{IFN}$ were administered $\mathrm{i} / \mathrm{v}$ at the same dose three times on the $10^{\text {th }}, 13^{\text {th }}$ and $15^{\text {th }}$ days and intranasally at dose $4 \cdot 10^{7}$ pfu per mouse five times on the $10^{\text {th }}, 13^{\text {th }}$ $16^{\text {th }}, 19^{\text {th }}$ and $22^{\text {nd }}$ days after transplantation of cells MM-4 for therapeutic purposes. For nasal injection the virus was slowly delivered as a bolus into the nostrils using a standard micropipette («Eppendorf», Germany) in a volume of $0.05 \mathrm{ml}$.

Ten mice in each group were used in experiments in vivo. The experiment was repeated twice. The dynamics of tumor growth in mice was investigated by measuring the tumor diameter every 2 days. The number of metastases was calculated on the $28^{\text {th }}$ day after transplantation of tumor cells. Volume of tumors and metastases in $\mathrm{mm}^{3}$ was determined by the formula $V=D^{3} \cdot 0.52$, where $V$ - volume of metastases; $D$ - diameter of a single tumor or metastasis.
Statistical analysis. Statistical data processing was performed by the Student $t$-test or nonparametric U-criterion Wilcoxon-Mann-Whitney using STATISTICA 6.0.

Results and discussion. We studied IFN production by MM-4 cells transduced by $\mathrm{rBV}$ and $\mathrm{rBV} / \mathrm{IFN}$ with different MOI in vitro. Concentration of mouse IFN-beta in culture medium of the transduced cells was determined by standard micromethod on antiviral activity. L929 cells and VSV were used as a test-system. It was found that the level of IFN-beta production depends on the dose of $\mathrm{rBV} / \mathrm{IFN}$. It was shown, that rBV without IFN gene does not induce endogenous IFN in MM4 cells (Table).

Production of recombinant IFN by melanoma cells resulted in a significant dose-dependent inhibition of cell growth compared to the control (cells transduced by rBV and untreated cells). In this case we observed an increase in doubling time of cells, a decrease in the number of cells in the phase of mitosis and a decrease in expression of the proliferation antigen Ki-67 (Table).

Our results showed that the level of expression of Ki-67 protein in the untreated MM-4 cells and those transduced by $\mathrm{rBV}$ did not differ and on average was $96 \%$ of cells. The percentage of Ki-67-positive cells $48 \mathrm{~h}$ after their transduction by rBV/IFN MM-4 cells was $39 \%$. These data indicate that exactly IFN-beta reduces proliferative potential of cells.

Morphological studies showed that the transduction of melanoma cells by rBV did not affect their morphology, but after transduction of MM-4 by rBV/IFN the cells we observed more epithelial-like morphology with increasing cell size and growth area.

Antibodies to IFN-beta showed that untreated and transduced by rBV MM-4 cells did not synthesize recombinant protein and $8.5 \pm 1.5 \%$ of cells synthesized IFN $20 \mathrm{~h}$ after $\mathrm{rBV} / \mathrm{IFN}$ transduction (Fig. 1). This 

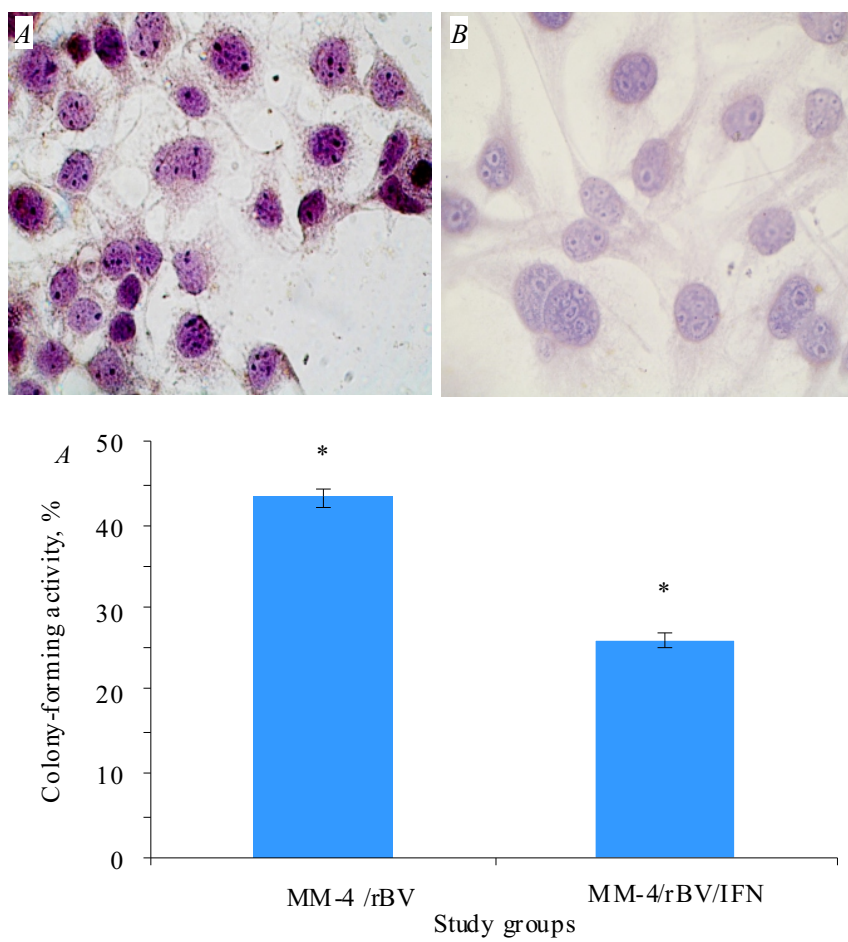

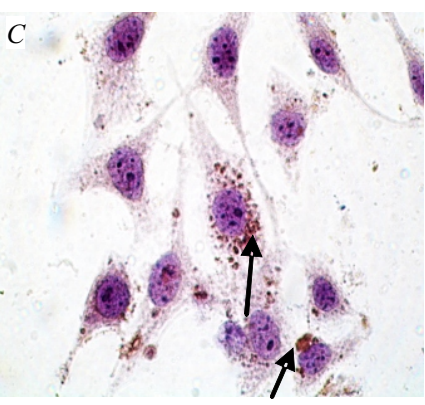

Fig. 1. The expression of recombinant murine IFN-beta in the MM-4 cells transduced by $\mathrm{rBV}$ and $\mathrm{rBV} / \mathrm{IFN}$ : $A$ - MM-4 control (untreated cells); $B-\mathrm{MM}-4 / \mathrm{rBV}$; $C-\mathrm{MM}-4 / \mathrm{rBV} / \mathrm{IFN} ;$ synthesis of recombinant IFN-beta

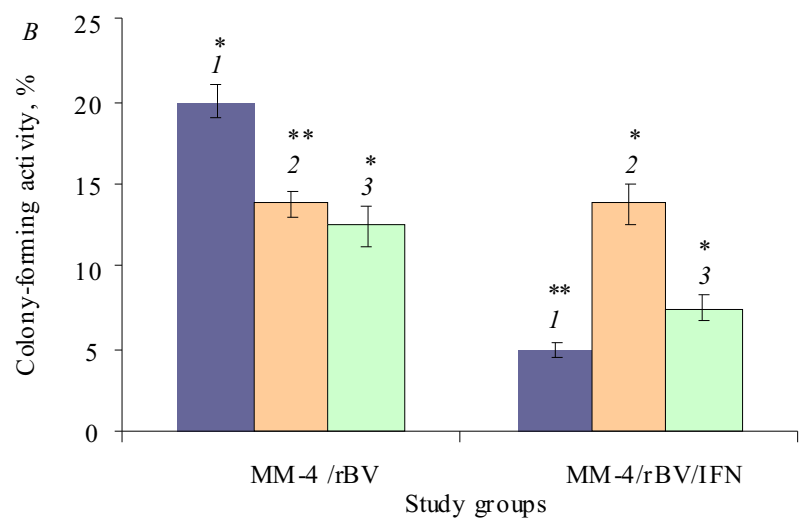

Fig. 2. $A$-inhibition effect of the recombinant mouse IFN-beta on platting efficiency of MM-4 cells in vitro (MOI $100 \mathrm{pfu} / \mathrm{cell} ; *^{*} \mathrm{p}<0.001 \mathrm{compa}-$ red to control); $B$ - analysis of the size of the colonies formed by MM-4 cells on substratum (*p $<0.001 ; * * \mathrm{p}<0.005$ compared to control); $1-$ large colonies ( $>50$ cells); 2 - middle colonies (21-50 cells); 3 - small colonies (10-20 cells)
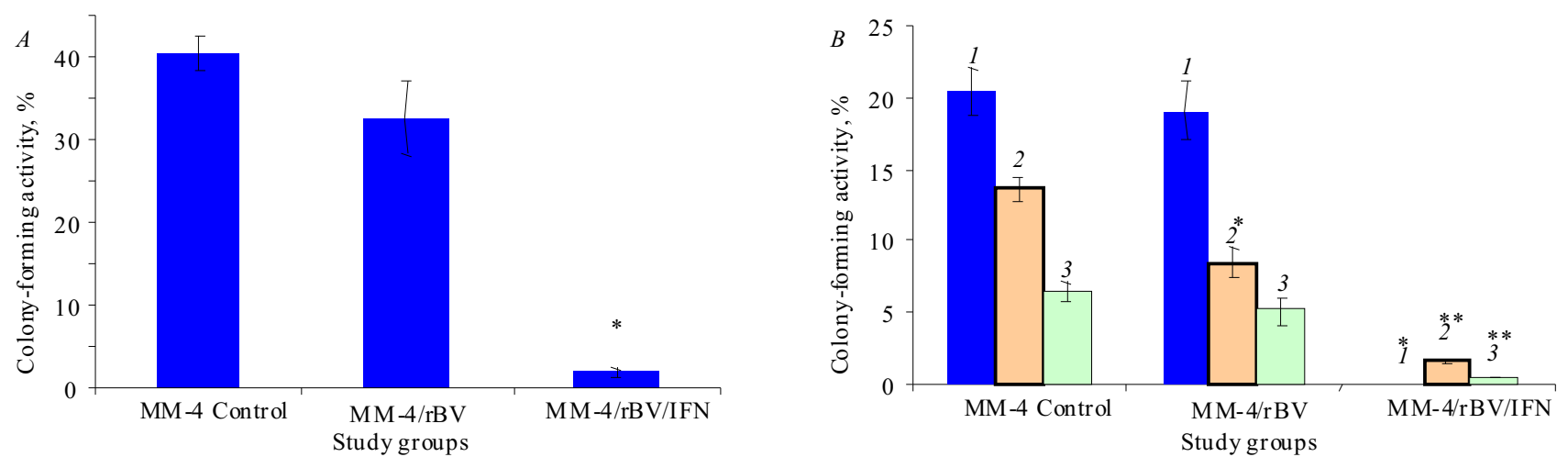

Fig. 3. $A$ - colony-forming activity of MM-4 in semisolid agar ( ${ }^{*} \mathrm{p}<0.005$ compared to control); $B$ - analysis of the size of the colonies formed by MM-4 cells in semisolid agar $(* \mathrm{p}<0.001 ; * * p<0.005$ compared to control). MM-4 control - untreated cells; MM-4/rBV - MM-4 cells, transduced with rBV(MOI 200 pfu/cell); MM-4/rBV/IFN - MM-4 cells, transduced with rBV/IFN (MOI 200 pfu/cell); $1-$ large colonies (> 50 cells); 2 - middle colonies (21-50 cells); 3 - small colonies (10-20 cells)

suggests that only a small percent of the cells synthesizing recombinant IFN can cause significant biological and phenotypical changes in tumor cells.

Our in vitro study of some biological parameters, which can indicate autonomy and tumorigenicity in transduced melanoma cells, showed that transduction of cells by $\mathrm{rBV} / \mathrm{IFN}$ significantly inhibited the platting efficiency of cells and their ability to form colonies in semisolid agar (Fig. 2, 3).
It is important, that IFN-transduction 10-fold inhibited both the number of cell colonies and quantity of large colonies in semisolig agar (Fig. 3). Our investigation of the colony-forming activity (CFA) of tumor cells showed that transduction of these cells by $\mathrm{rBV} / \mathrm{IFN}$ resulted in significant inhibition of tumorigenicity of cells. The levels of CFA inhibition of MM-4 cells are IFN dose-depending: a higher titer of IFN production leads to the greatest reduction in CFA of tumor cells - up to 


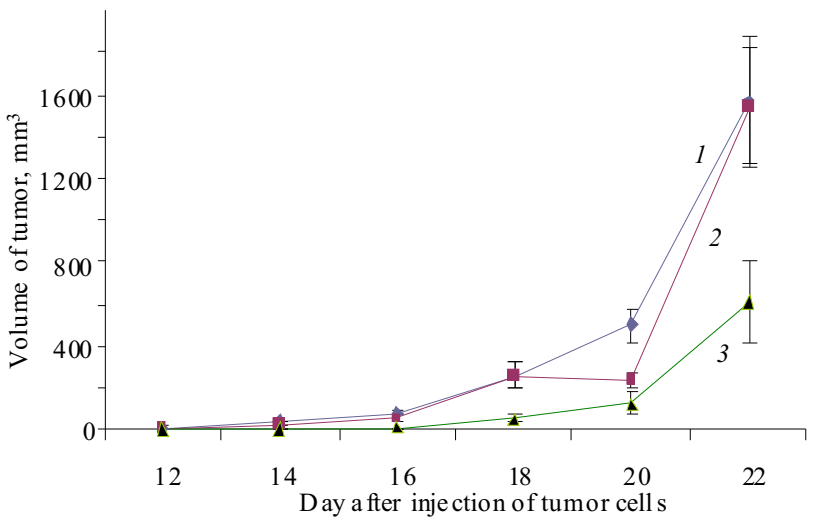

Fig. 4. Kinetics of melanoma growth in mice after $\mathrm{i} / \mathrm{m}$ injection of MM-4 cells: 1-blue - MM-4 control (untreated cells); 2-red MM-4/rBV (MM- 4 cells, transduced with rBV; MOI $100 \mathrm{pfu} / \mathrm{cell}$ ); 3-green - MM-4/rBV/IFN (MM-4 cells, transduced with $\mathrm{rBV} / \mathrm{IFN}$; MOI $100 \mathrm{pfu} / \mathrm{cell})$

20 times compared to control at MOI $200 \mathrm{pfu} / \mathrm{cell}$ (at MOI $100 \mathrm{pfu} / \mathrm{cell}$ the data on CFA of transduced MM-4 cells are not shown). It is also obvious that the antitumor activity of IFN-transgene expression was of paracrine nature and prolonged in time, because the inhibition of clonal cell growth was observed for at least 2 weeks after the transduction and antiproliferative effect of IFN-transgene spread on all the cells in the culture, and not only on the IFN-producing cells.

Thus, these data suggest that the transplantation of IFN-producing tumor cells transduced by $\mathrm{rBV} / \mathrm{IFN}$ in vivo can result in a gradual increase in local concentration of IFN in the area of the injection of these cells and inhibition of tumor growth.

In the second series of experiments the effect of $\mathrm{rBV} / \mathrm{IFN}$ on tumorigenicity and character of melanoma growth was examined under condition of the $\mathrm{i} / \mathrm{m}$ administration of cells. The studies have shown that transduction of MM-4 cells with $\mathrm{rBV} / \mathrm{IFN}$ significantly inhibits the kinetics of melanoma growth in mice (Fig. 4).

In the control mice the tumor growth was registered in $100 \%$ of mice already on the 8-10 days after transplantation, while the tumor growth in mice injected with the cells transduced by rBV/IFN on the 18 day was absent.

Tumors also occurred in all mice of this group later, but the inhibition of tumor growth on the 22 day compared to control amounted to $61.3 \pm 18.6 \%$. In the control mice the MM-4 tumor volume was $1569 \pm 292 \mathrm{~mm}^{3}$, whereas in the animals of experimental group with
$\mathrm{rBV} / \mathrm{IFN}$ - only $607.8 \pm 191 \mathrm{~mm}^{3}(\mathrm{p}<0.02)$. These data suggest that the presence of small quantities of tumor cells producing IFN-beta is attended with a significant inhibition of tumor growth.

It was important to research whether $\mathrm{rBV} / \mathrm{IFN}$ transduces the tumor cells MM-4 under the in vivo condition and to determine the therapeutic effect of $\mathrm{rBV} /$ IFN after its injection directly in tumor tissue.

In two independent experiments we revealed that tumorigenicity of cells ( $\%$ of mice with tumor), as well as kinetics of tumors growth after $\mathrm{i} / \mathrm{t} \mathrm{rBV} / \mathrm{IFN}$ administration did not differ from those in the mice of control group. These data suggest that $\mathrm{i} / \mathrm{t}$ injection of $\mathrm{rBV} / \mathrm{IFN}$ did not result in antitumor effects of IFN, possibly because in vivo the tumor cells were not transduced by $\mathrm{rBV} / \mathrm{IFN}$ or the number of cells capable to produce IFN-beta was extremely low compared to the tumor size - by the $10^{\text {th }}$ day of tumor growth the malignant cells can exceed $10^{8}$.

The study showed that the transduction of melanoma cells by $\mathrm{rBV} / \mathrm{IFN}$ reduced their metastatic ability, which manifested in a decrease in the volume of metastasis by 5 times and the number of metastases by 10 times compared to control (Fig. 5). Moreover, metastasis formed in $80 \%$ mice of this group.

Therapeutic $\mathrm{i} / \mathrm{v}$ administration of $\mathrm{rBV} / \mathrm{IFN}$ on the $10^{\text {th }}, 13^{\text {th }}$ and $15^{\text {th }}$ days after $\mathrm{i} / \mathrm{v}$ MM-4 cells transplantation results in significant inhibition of growth of metastases in lungs of mice: a decrease in the volume of metastasis by about 7 times and the number of metastases by 10 times (Fig. 6). In this case, metastasis wasn't observed in $10 \%$ of mice.

Interestingly, IFN in blood of mice injected by $\mathrm{rBV} /$ IFN or by its transduced MM-4 cells was not detected. This indicates that IFN realized antimetastatic effects by its local production in metastatic lesions. Based on the fact that micrometastases in lungs of mice by the $10^{\text {th }}$ day after injection of melanoma cells were already formed, we consider that $\mathrm{i} / \mathrm{v}$ introduction of $\mathrm{rBV} / \mathrm{IFN}$ directly induced the regression of metastases number and volume. The mechanisms of this process may include the activation of nonspecific and specific circuits of the immune system, direct inhibition of tumor cell proliferation and inhibition of neoangiogenesis.

Thus, these data suggest that the transplantation of IFN-producing tumor cells transduced by $\mathrm{rBV} / \mathrm{IFN}$ in 

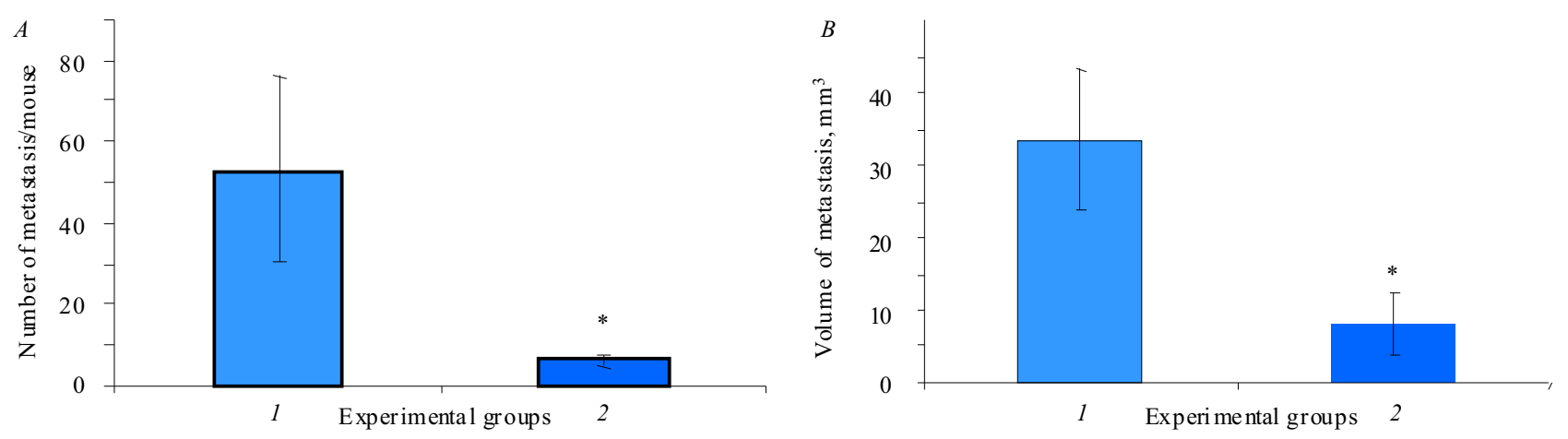

Fig. 5. Metastatic potential of MM-4 cells ( ${ }^{*} \mathrm{p}<0.05$ compared to control): 1 - MM-4 (control - untreated cells); $2-\mathrm{MM}-4 / \mathrm{rBV} / \mathrm{IFN}(\mathrm{MM}-4$ cells, transduced with $\mathrm{rBV} / \mathrm{IFN}$; MOI $100 \mathrm{pfu} / \mathrm{cell})$
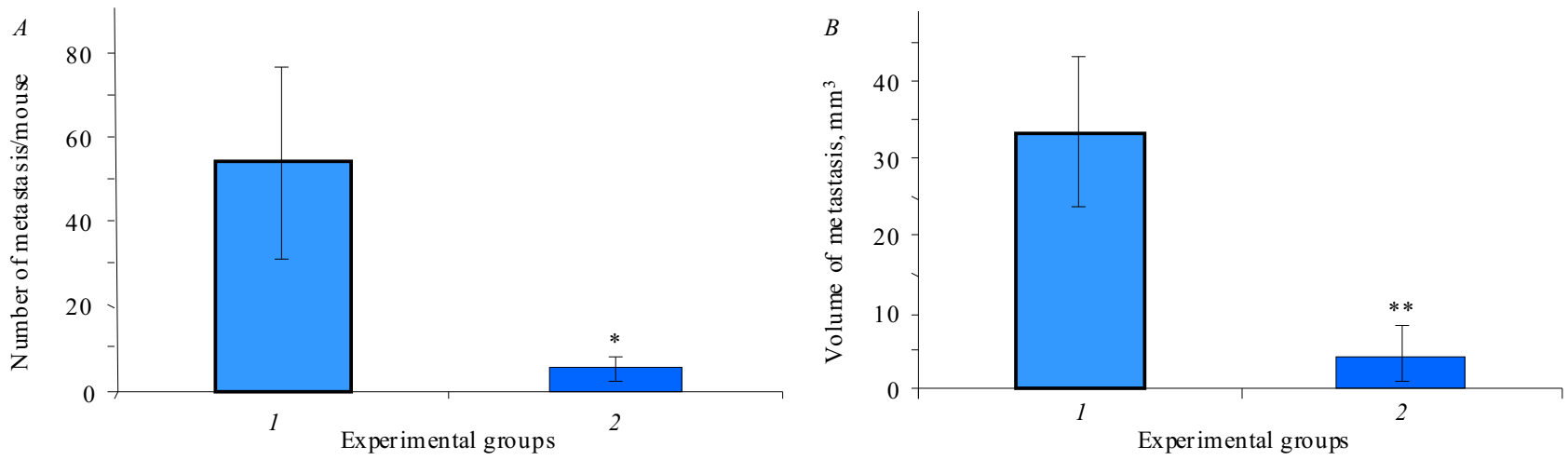

Fig. 6. Inhibition of metastatic melanoma growth in the lungs of C57BL/6 mice at therapeutic i/v introduction of rBV/IFN: $1-\mathrm{MM}-4$ (control untreated cells); $2-\mathrm{MM}-4$ untreated cells $+\mathrm{i} / \mathrm{v}$ introduction of $\mathrm{rBV} / \mathrm{IFN}$

vivo can lead to a gradual increase in local concentration of IFN in the area of the injection of these cells and to the inhibition of tumor growth.

At the same time, a fivefold intranasal injection of $\mathrm{rBV} / \mathrm{IFN}$ does not reduce the metastatic potential of MM-4 cells: the number of metastases in control and experimental groups does not differ significantly (data not shown).

Conclusions. 1. Transduction of melanoma B16 MM-4 cells by $\mathrm{rBV} / \mathrm{IFN}$ is followed by synthesis and production of biologically active IFN-beta which leads to inhibition of their proliferative and tumorigenic potential in vitro and in vivo.

2. rBV did not induce IFN in melanoma cells and did not inhibit their proliferation and tumorigenicity. Such a virus (at a dose of less than $10^{8} \mathrm{pfu}$ ) did not induce IFN at the system level and showed no antitumor activity after in vivo introduction.

3. Transduction of melanoma cells with $\mathrm{rBV} / \mathrm{IFN}$ inhibits their ability to form solid tumors and metastases in the lungs of mice.
4. Introduction of $\mathrm{rBV} / \mathrm{IFN} \mathrm{i} / \mathrm{t}$ or $\mathrm{i} / \mathrm{n}$ does not affect tumor growth and metastasis, but this agent significantly inhibits the growth of metastatic nodes in the lungs when introduced $\mathrm{i} / \mathrm{v}$.

Acknowledgements. We would like to thank L. I. Strokovska, A. P. Solomko, E. A. Zaharuk, O. V. Anoprienko, I. N. Vagyna (Institute of Molecular Biology and Genetics, NAS of Ukraine) for providing recombinant baculovirus vectors.

Fundings. This study was supported by the grant $\mathrm{N}$ 11/2011 of President of Ukraine for young scientists.

Пригнічення онкогенності і метастатичного потенціалу клітин меланоми методом трансдукції їх геном інтерферону

О. О. Лихова, Ю. Й. Кудрявець, Н. О. Бездєнєжних, Н. І. Семесюк, I. М. Адаменко, А. Л. Воронцова

Резюме

Мета. Вивчення інгібувального ефекту трансдукиії клітин меланоми миші рекомбінантним бакуловірусом з геном інтерферону-бета миші in vitro та in vivo. Методи. Дослідження проведено на моделі меланоми миші В16 (клітинна лінія ММ-4) з використаннням трансдукції клітин рекомбінантним бакуловірусом, імуно- 
цุитохімічного аналізу та методів дослідження біологї̈ пухлинної клітини. Результати. Трансдукиія клітин ММ-4 рекомбінантним бакуловірусом з геном ІФН-бета миші призводить до змін морфології пухлинних клітин, пригнічення клітинної проліферації, значного інгібування посадкової ефективності та колонієутворювальної активності у напіврідкому агарі. Крім того, трансдукиія клітин меланоми ММ-4 бакуловірусом з геном ІФН-бета пригнічує онкогенність і метастатичний потенціал клітин іп vivo. Внутрішньовенне введення рекомбінантного бакуловірусного вектора з геном ІФН-бета інгібує ріст метастазів меланоми в легенях мишей, яким внутрішньовенно введено пухлинні клітини. Висновки. Трансдукиія клітин меланоми миші рекомбінантним бакуловірусом з геном IФHбета миті пригнічує їхній проліферативний потенціал, а також онкогенну і метастатичну активність.

Ключові слова: інтерферон, рекомбінантний бакуловірус, трансдукиія, клітини меланоми, онкогенність, метастазування.

Подавление онкогенности и метастатического потенциала клеток меланомы методом трансдукции их геном интерферона
А. А. Лихова, Ю. И. Кудрявец, Н. А. Безденежных,
Н. И. Семесюк, И. Н. Адаменко, А. Л. Воронцова

Резюме

Цель. Изучение ингибирующего эффекта трансдукиии клеток меланомы мыши рекомбинантным бакуловирусом с геном интерферона-бета мыши in vitro u in vivo. Методы. Исследование проведено на модели меланомы мыши В16 (клеточная линия ММ-4) с использованием трансдукции клеток рекомбинантным бакуловирусом, иммуноцитохимического анализа и методов исследования биологии опухолевой клетки. Результаты. Трансдукиия клеток ММ-4 рекомбинантным бакуловирусом с геном ИФН-бета мыши приводит к изменениям морфологии опухолевых клеток, подавлению клеточной пролиферачии, значительному ингибированию посадочной эффективности и колониеобразующей активности в полужидком агаре. Кроме того, трансдукиия клеток меланомь ММ-4 бакуловирусом с геном ИФН-бета подавляет онкогенность и метастатический потенциал клеток іп vivo. Внутривенное введение рекомбинантного бакуловирусного вектора с геном ИФНбета ингибирует рост метастазов меланомы в легких мышей, которым внутривенно введены опухолевые клетки. Выводы. Трансдукция клеток меланомы мыши рекомбинантным бакуловирусом с геном ИФН-бета мыши подавляет их пролиферативный потеничиал, онкогенность и метастатическую активность.

Ключевые слова: интерферон, рекомбинантный бакуловирус, трансдукиия, клетки меланомы, онкогенность, метастазирование.

\section{REFERENCES}

1. Wadler S, Schwartz EL. New advences in intrerferon therapy of cancer. Oncologist. 1997; 2(4):254-67.

2. Abelev GI, Altshtein AD, Belitsky GA, Vasiliev JM, Morozov VA, Myasishcheva NV. Carcinogenesis. Ed. D. G. Zaridze. Moscow: Nauchny mir, 2000; 418 p.
3. Ferrantini M, Capone I, Belardelli $F$. Interferon-alpha and cancer: mechanisms of action and new perspectives of clinical use. Biochimie. 2007; 89(6-7):884-93.

4. Jonasch E, Haluska FG. Interferon in oncological practice: review of interferon biology, clinical applications, and toxicities. Oncologist. 2001; 6(1):34-55.

5. Qin XQ, Tao N, Dergay A, Moy P, Fawell S, Davis A, Wilson $J M$, Barsoum $J$. Interferon-beta gene therapy inhibits tumor formation and causes regression of established tumors in immunedeficient mice. Proc Natl Acad Sci USA. 1998; 95(24):14411-6.

6. Belzhelarskaya $S N$. A baculovirus expression system for insect cells. Mol Biol (Mosk). 2002; 36(3):371-85.

7. Lackner A, Kreidl E, Peter-Vorosmarty B, Spiegl-Kreinecker S, Berger $W$, Grusch $M$. Stable protein expression in mammalian cells using baculoviruses. Methods Mol Biol. 2012; 801:75-92.

8. Airenne KJ, Mahonen AJ, Laitinen O, Yla-Herttuala S. Baculovirus-mediated gene transfer: an evolving new concept. Gene and Cell Therapy. Therapeutic Mechanisms and Strategies. Ed. N. S. Templeton. New York: CRC Press, 2003;181-97.

9. Vagyna IN, Anopriyenko OV, Zaharuk OA, Gorchev VF, Strokovska LI, Solomko AP. Efficient gene delivery into mammalian cells by baculovirus vector in vitro. Biopolym Cell. 2008; 24(6): $508-12$.

10. Vagyna IN, Anopriyenko OV, Zaharuk EA, Morozova LM, Strokovska LI. Inhibition of growth of mouse melanoma fetal fibroblasts which express IFN-B in vivo. Achievements and problems of genetics, breeding and biotechnology. Ed. V. A. Kunakh. Kyiv: Logos, 2012; Vol. 4:291-7.

11. Kudryavets YuI. Mouse melanoma cell line spontaneously producing C-type virions. Mat. $7^{\text {th }}$ Conf. «Problems of Microbiology and Virology». Riga: Zinatne, 1977;162-3.

12. Skivka L, Susak Y, Trompak O, Kudryavets Yu, Bezdeneznikh N, Semesiuk N, Lykhova O. The effect of monotherapy and combined therapy with NSC-631570 (ukrain) on growth of low- and high-metastasizing B16 melanoma in mice. J Oncol Pharm Pract. 2011; 17(4):339-49.

13. Vorontsova AL, Kudryavets YuI, Fadeev VA, Balitskii KP. Antimetastatic effects of interferon in the surgical removal of experimental tumors. Exp Oncol. 1983; 5(5):45-9.

14. Gluzman DF, Abramenko IV, Skliarenko LM, Kryachok IA, Nadgornaya VA. Diagnosis of leukemia. Atlas and practical guide. Kiev: Morion, 2000; 224 p.

15. Vega-Avila E, Pugsley MK. An overview of colorimetric assay methods used to assess survival or proliferation of mammalian cells. Proc West Pharmacol Soc. 2011; 54:10-4.

16. Hamburger $A W$, Lurie $K A$, Condon ME. Stimulation of anchorage-independent growth of human tumor cells by interleukin 1 . Cancer Res. 1987; 47(21):5612-5.

17. Zhang $X, X u L, Y u Q$. Cell aggregation induces phosphorylation of PECAM-1 and Pyk2 and promotes tumor cell anchorageindependent growth. Mol Cancer. 2010; 9:7.

Received 11.06.13 